\title{
LITERATURE
}

SERCAN ÖZTEKIN ${ }^{7}$

DOI: 10.15290/CR.2021.32.1.03

Kocaeli Univesity, Turkey

ORCID: 0000-0003-1021-8460

\section{Subversion of gender stereotypes in Wilkie Collins's The Woman in White and Mary Elizabeth Braddon's Lady Audley's Secret}

\begin{abstract}
Victorian sensation fiction strives to go beyond its time through issues and characters that do not conform to nineteenth century social norms. The novels of this genre depict the sensational lives with deceits and crimes which shocked the readers of their time, and they increase the reader's tension with sensational narratives including untraditional matters and portrayals. Along with scandalous and criminal subjects, these works sometimes offer unconventional depictions of femininity and masculinity in the Victorian Age. Accordingly, this paper discusses Wilkie Collins's The Woman in White (1860) and Mary Elizabeth Braddon's Lady Audley's Secret (1862) focusing on male and female characters challenging traditional gender stereotypes. It examines how these novels describe characters rather dissimilar to the ones in the traditional fiction of the era through their cunnings, intrigues, and unconventional attitudes with regard to marriage, power, and gender roles.
\end{abstract}

Keywords: Victorian sensation fiction, subversion, gender, femininity, masculinity.

\section{Introduction}

The Victorian novel is generally identified by attempts for realistic descriptions of difficult situations in which middle class and urban society struggle, together with portrayals of traditional gender roles. However, some novels, especially of sensation fiction in the 1860s, strive to go beyond their time through issues and characters that do not

7 Address for correspondence: Kocaeli Universitesi, Korfez Yerleskesi, Yabanc1 Diller Yuksekokulu, Atalar Mah. Bağdat Cad. No:83, Korfez/Kocaeli, Turkey. E-mail: sercan.oztekinn@gmail.com 
conform to nineteenth century social norms. These novels depict the sensational lives with deceits and crimes which shocked the readers of their time. D. A. Miller states that they represent "the first instances of modern literature", as they include sensational narratives including untraditional subjects and portrayals (1986: 107). Along with scandalous and criminal subjects, these works offer unconventional depictions of femininity and masculinity in the Victorian Age. Concerning subversions of gender stereotypes, this paper discusses Wilkie Collins's The Woman in White (1860) and Mary Elizabeth Braddon's Lady Audley's Secret (1862) which are among the most prominent examples of sensation fiction. They describe the characters rather dissimilar to the ones in the traditional fiction of the era through their cunnings, intrigues, and unconventional attitudes with regard to marriage, power, and gender roles.

As a result of their revolutionary and modern contents compared to strict moral codes of the Victorian age, sensation novels were harshly criticized for being indecent and outrageous. Ross G. Forman points out that the antagonistic critical responses against sensation novels manifest not only male unease about female writers and readers, but also anxieties about unconventional portrayals of gender and marriage in these works (2011: 415). Emily Allen emphasizes "the sensations novel's shocking and scintillating representation of women and men gone off the rails of proper gender: manly women, effeminate men, and most variants in between" (2011: 401). These novels attempt to shatter the patriarchal order and sexual inequality, which could be seen in the regulations of certain acts that granted women significant rights in the second half of the nineteenth century. Actually, the domestic female ideal started to be challenged before the popularity of sensation fiction. The Matrimonial Causes Act of 1857 (or the Divorce Act) for the first time gave neglected or mistreated middle-class women right to sue their husbands for divorce, so they could legally leave their houses where they were supposed to be the 'angels'. Additionally, the Married Women's Property Act of 1870 allowed women to control their own property and fortune (Allen 2011: 404). Sensation novels reflect on these social transformations and trigger them as well, for they display unconventional matters and question traditional gender conventions and identities.

These works also criticize and deconstruct strict heterosexuality and gender stereotypes of the Victorian period. The terms "homosocial" and "homoerotic" are used in this paper, as there are not obvious same-sex relationships in the two novels studied, but the same-sex desire could be relatively observed in some certain characters. Eve Kosofsky Sedgwick, in Between Men: English Literature and Male Homosexual Desire (1985), defines homosociality as any kind of the social bonds between people of the same-sex. However, she mostly applies this term to men due to the control of patriarchal system over unusual relationships between men in order for this system to emphasize heterosexuality. The boundaries between homosocial and homosexual relationships could be blurry, so patriarchal system develops a homophobic language in order to eliminate male 
homosexuality. Sharon Marcus, in Between Women (2007), an allusion to Sedgwick's work, focuses on the relationships between women in the Victorian age. She accepts Segdwick's proposition that female homoerotic relationships did not get as much attention as male homoeroticism, and she states that these female bonds need more critical investigation. Additionally, Paul Hammond describes the difference between homoerotic and homosexual: "homoerotic" refers to feelings, but not exactly to sexual acts addressed from one man to another; these feelings may never be set in motion as they would in a "homosexual" involvement (1996: 5). In the works discussed in this paper, these homoerotic overtones can be read as a form of subversion of traditional male and female identities.

\section{Subversion of traditional female identity}

One of the most important atypical subjects in Victorian sensation fiction is the masculinization of some female characters. It can be recognized more obviously in The Woman in White which is one of the earliest examples of sensation fiction with its serialization started in 1859. It starts with the story of a painting teacher Walter Hartright who goes to Limmeridge House to teach Laura Fairlie and Marian Halcombe, the stepsisters. An heiress to her late father's property, Laura is promised to Sir Percival Glyde who turns out to be after her fortune. Walter Hartright, with Marian's help, traces Sir Percival and his ally Count Fosco to save Laura from her marriage and the stealing of her fortune. Marian Halcombe is described as a masculine and ugly woman in the first scene where Walter meets her. She is an "ugly" lady with "a large, firm, masculine mouth and jaw" (24), and this description is maintained through the depiction of her head's contradicting with her "masculine form" (25) and body. This narration goes far even to describe "almost a moustache" (25) on her upper lips, and that makes her masculinity definite once again. This could be regarded as disturbing because she is in striking contrast to usual figures of submissive women which were social constructs in the Victorian age.

In addition to her masculine physical appearance, Marian is also a strong and courageous character compared to figures of traditional women who are generally dominated by male power in Victorian fiction. She is often identified with masculine definitions which stand for transgression of gender identity. As Miller points out, her curios case of having a masculine body "gives all the hints of containing a man's soul" (1986: 125). She is a mentor and protector to Laura at home even after her sister gets married. Rational thinking is embodied in Marian while Laura is incapable of doing anything alone without Marian's help. Marian has a great influence on some incidents throughout the story. In the beginning, she is the one who decides that Walter cannot stay in their house anymore because of his attraction to Laura, and she gets him to leave in a very short time. Laura is saved by Marian after she is kept in the asylum in place of Anne Catherick. As Laura's health is heavily affected by the events, Marian takes an active parental role in her caring. Furthermore, after getting alarmed by the danger of 
being found, she moves Laura to another place even though Walter is not there to help them. As observed, Marian's identification on gender terms is vague even when Count Fosco asks, "Can you look at Miss Halcombe and not see that she has the foresight and the resolution of a man?” (291). As Carolyn Dever points out, Marian's gender identity and features are ambiguous, and "her sexuality is also open to interpretation" (2005: 166). Accordingly, her relationship with Laura and her gender identity not conforming to Victorian norms evoke female homoerotic overtones which prevail in the novel.

Homoerotic intimations in The Woman in White are strengthened through Marian's masculinity and characterization. Anyone would suspect the peculiarity of the relationship between Marian and Laura because they are depicted as being extremely close to each other despite being totally different in character and appearance. Their intimacy is so apparent that it must have been confusing and inconvenient to the Victorian society. Peter Barry states that homosexual implications can be a metaphorical allusion to the act of exceeding the limits and "resistance to the established norms and boundaries" (2002: 148). Therefore, this issue is dealt with in the novel as a means of being different and unconventional in a very conservative period. The fact that there are no parents in their life, but only an uncle who keeps himself closed in a dark room, implies the idea of freedom for these female characters and their homosocial bonds. They have nothing to limit them and this freedom has possibly made them quite intimate and dependent on each other. In spite of their differences, Marian says "I won't live without her and she can't live without me" (27). This shows their unusual relationship when she talks as if they were two passionate lovers who can't be without each other. Marian continuously indicates her hate for Sir Percival and she describes Laura as her "own love" (171). She does anything for Laura, so she is not afraid of taking risks. Thus, this desire and love for each other suggest more homoerotic overtones rather than mere homosociality in Sedgwick's term.

Marriage does not have any significance to Marian, and she does not have any intention of marrying someone. As Laurel Erickson points out, she breaks away from the predestined life of a single young woman caught in marriage plot (1999: 100). As there is no authority to make her get married to a baronet or a socially higher aristocrat, she takes it for granted to live with her half-sister. Besides, the reader is not presented any hints of her interest in the opposite sex, for she is totally committed to her half-sister. While Marian does not trouble herself about not getting married, her half-sister has to marry Sir Percival due to her promise and loyalty to her dead father. Nonetheless, they promise each other to live together after Laura gets married, and she even gets Marian to "repeat the promise to live with her when she was married" (159). In a totally depressing mode, they spend the night together in the bed before Laura's marriage. The bond between them seems inseparable because Marian is always present in Laura's two marriages, the one with Sir Percival and the second one with Walter. 
Marian's attitude and remarks about men represent the unconventionality and refusal of male oppression explicitly:

No man under heaven deserves these sacrifices from us women. Men! They are enemies of our innocence and our peace - they drag us away from our parents love and our sisters' friendship - they take us body and soul to themselves, and fasten our helpless lives to theirs as they chain up a dog to his kernel. (159)

Her severe reaction to men and their selfishness could be recognized as a form of rebellion by any attentive reader. With respect to Collins's fiction, Lyn Pykett postulates how society is sometimes "threatened by an 'emasculating' primitive womanly nature, by women who do not know- or who refuse to accept- their assigned place in society; by feminized men, or by coarse brutal masculinity" (2005: 124). Marian is rather conscious about helplessness of her life unlike any other Victorian women who accept to be controlled by men. She considers men as enemies of their freedom and their peace. As there are not any parent figures, she means her sister's love even when she mentions parents' love. A dog in chains as a metaphor for a woman under male control is also quite shocking for the conservative Victorian norms.

Anne Catherick's mother is another significant figure in this regard, though she is not seen much throughout the story. She has been cheated by Percival and made to plot on behalf of him, so she becomes his accomplice. Then, she becomes a threat to Percival, and he is forced to support her financially. Society considers her a fallen woman, and her husband just abandons her because she is believed to have had an affair with Percival. However, she is an arrogant and dominant woman who does not care about what people think of her. She does not cry or beg her husband not to leave her, and she does not try to make people believe that she is not guilty either. She is a significant representative of a non-conformist female in a traditional society.

In a similar vein, Mary E. Braddon's Lady Audley's Secret tells the story of an unconventional woman and makes a very formidable female character central to a sensational story. While Lady Audley's past, being left with a child by her husband, represents the traditional phase of Victorian femininity, her later marriage with Mr. Audley is her struggle against women's misery caused by male domination. In Natalie Schroeder's words, Braddon's "sensation novels are especially significant today for what they reveal about Victorian women's resistance to conventionally prescribed social norms" (1988: 87). In the novel, Helen Talboy cannot bear anymore being a desperate mother waiting for her husband to come back from Australia. For this reason, she fakes her death and changes her name to Lucy Graham in search for a different life and a rich husband. She gets married to Mr. Audley, a rich but old gentleman. When her ex-husband shows up 
with her new husband's nephew coincidentally, she enforces her limits in order not to disclose her secret past.

Like Marian Halcombe, Lady Audley has countless unconventional attributes with regards to her power to achieve what she desires. She is intelligent and brave enough to change her identity and make a new start in her life. Besides, she is fearless when she pushes her former husband, George Talboy, into the well and burns an inn down with the aim of killing the owner of the place. While doing so, she gets help only from another female, her maid Phoebe, not a man. Likewise, Laura receives the greatest support from Marian till Walter gets involved in the case.

Besides unorthodox attributions to her, she is also described as a representation of evil with abundant descriptions in the novel due to her irrepressible anger. Hansson and Norberg state how the relation between her and evil is clear in her portrayal and she is associated with the devil through certain metaphors (446). The "flame in her eyes - a greenish light, such as might flash from [...] an angry mermaid" (347) and the "horrible demoniac force" (351) present her like a monstrous creature. In a way, Lucy reacts against the male dominated Victorian norms by committing bigamy. As these suggest, "women offer a formidable, and frequently insurmountable, challenge to heterosexual male figures in Victorian fiction" (Dever 2005: 171). Lucy cannot wait for a husband whose whereabouts are unknown, and acts for herself in order to have a better life by changing her name and marrying another man.

Furthermore, marriage is a controversial issue in the novel in comparison to traditional social aspects. Lucy gets married only in an attempt to climb socially and have a more comfortable life, most importantly to be free. She regards marriage as a way to freedom because she can get whatever she wants in this way. Mr. Audley does not have any sexual relationship with her; in addition, she does not have passion for that. Homoerotic overtones between Lady Audley and Phoebe raised by Schroeder are not as obvious as in Marian and Laura's relationship. Although Lucy's opposition to Phoebe's marriage to Luke can be associated to their affection, there is another important reason for her refusal. She does not want this marriage because Luke is extremely abusive, and she does not want Phoebe to be oppressed by him. As all these circumstances signify, Lady Audley violates gender, social, and moral codes and she is eventually put into the asylum by a consensus in a patriarchal order (Klein 2008). That also shows how untraditional female characters are not tolerated in Victorian society, which could be related to her demon-like depiction in some parts of the novel.

\section{Challenging Victorian masculinity}

Together with unusual female characters, male characters are presented as incapable of controlling women and displaying manly features as opposed to expectations. Victorian masculinity is open to interpretation in these two novels because male characters are 
deconstructed through their weakness and incapacity. In The Woman in White, Walter Hartright is usually presented as less capable than Marian and in need of her help. Marian regards Walter as feminine, and often urges him to act like a man: “Don't shrink under it like a woman [...] trample it under foot like a man" (59). This posits a total contrast between these characters who are supposed to possess social characteristics of their sex. Marian's statement indicates Walter's weakness at the same time. He belongs to the lower-middle class, which signifies his weakness compared to financially superior women around him. However, he eventually manages to get married to Laura at the end.

Walter is a socially inferior man to his beloved Laura and undertakes an amateur detective position for the sake of the re-establishment of her identity. When Laura is saved from the asylum, and her social identity and position are assured, Walter gets married to her and becomes the "heir of Limmeridge" (569). It can be inferred that Marian only accepts Walter as Laura's husband because of his lower social position and fragility. Furthermore, they will also live together and Marian will possibly never get married. In this way, Walter becomes a conduit in their relationship and he will always feel inferior because of their different social status. That means Marian can dominate and control the couple, for Laura is still psychologically and physically weak after all the traumatizing experiences.

Described as a rival to Walter and Marian, Sir Percival is not a very dominant and strong man, as he cannot get Laura to sign a document about using her fortune. Although he is an upper class gentleman, he does not possess virtuous merits and attitudes supposed to be in a so-called aristocrat and educated man like him. He can lose his temper easily for which Count Fosco criticizes him and advises him to be more rational. However, Sir Percival is a representative of fake aristocracy who does not have that virtues belonging to upper class gentility. He cannot even think rationally when it comes to the obsession to keep his secrets hidden. As Ross G. Forman proposes, Sir Percival's "bullying, bad temper, and disrespect for honor mark him as outside the bounds of appropriate manliness for his class", and also as opposite to traditional standards of being a gentleman for the middle class readers. (2011: 417). What is more, he is incapable of thinking sensibly and making plans in contrast to Marian whose nerves are strong.

Sir Percival's ineffectiveness as an unusual aristocrat makes his masculinity and sexuality questionable. Emily Allen describes him as "the novel's whipping boy of effeminate and hysterical masculinity, the ineffectual patriarch whose malignant selfishness dooms the woman in his charge" (2011: 407). When Laura and Sir Percival come back from their honeymoon, Laura's depressed mood gives the hints of sexual abuse or Glyde's indifference to Laura sexually and emotionally. He does not show any affection to Laura, which shows his ambition for financial gain in this marriage. Furthermore, his previous connection to Mrs. Catherick whom he used for creating his fake aristocracy is questionable. Although his attachment to Mrs. Catherick was identified as an 
illicit love affair by the villagers, it is later understood that it does not contain sexual matters. Sir Percival uses Mrs. Catherick in order to forge his parents' marriage record to legalise his heirship for his father's inheritance. Thus, he takes advantage of these accusations about him and Mrs. Catherick.

There are two other eccentric male characters in the novel that stand for subversion of masculinity. Philip Fairlie is Laura's uncle and he never gets out of his room because of his illness. He is deliberately described as a fragile and feminized man with no physical or masculine strength. He is totally careless for what goes on about his nieces, and he cannot perform any parental or masculine help for the sisters. Furthermore, Count Fosco is a really flamboyant man with his exaggeratedly polite and effeminate manners. He has a bizarre interest for his birds and flowers, which contrasts with the figure of a masculine gentleman. Although these two men seem socially and financially powerful, they do not have many qualities and features considered to be typical of men. In other words, they do not perform the characteristics of independent and strong upper class gentlemen in their actions and decisions.

In addition to these subversions of masculinity, Lady Audley's Secret displays homoerotic overtones between two male characters more obviously than any other sensation novel, and this has often been analysed in queer studies. Gero Bauer highlights the homosocial bonds between George and Robert, and Robert's affection for George is observed in "his eroticised search for his friend" (2016: 158). Moreover, Sedgwick relates homophobia to patriarchal system which dominates not only women but also homosocial bonds between men; that is, it oppresses both women and homosexuality to reinforce male power in society (Sedgwick 1985: 3). Therefore, Mary E. Braddon explicitly challenges the patriarchal order by employing a non-conformist woman and homoerotic bonds between men, both of which were harshly judged in the Victorian age. She depicts uncommon forms of masculinity with a homoerotic relationship and demasculinized men deliberately deconstructing masculinity in order to react against the mainstream Victorian patriarchy and sexual inequality.

Robert Audley, Sir Audley's nephew, functions as an amateur detective to find George Talboy and the secrets of Lady Audley. The things that make him a remarkable character are the homoerotic overtones associated with him and his relationship with George Talboys throughout the novel. In the initial presentation of Robert, he is concurrently depicted as both lethargic and obscurely effeminate. Braddon writes that he is a "handsome, lazy, care-for-nothing fellow of about seven and twenty" who likes "reading French novels" (36). He wears a blue silk handkerchief around his neck and his apartment is decorative, with flowers and birds in cages, which is alike to Count Fosco's extravagant dressing style and interest in birds. Therefore, Braddon forms a connection between Robert's refusal to adjust to strict gender conventions and his flamboyant manner of dress and fondness for French literature, a symbol of sexually immoral material. 
Jennifer S. Kushnier emphasizes the significance of Eton College as an implication for the nature of Robert and George's relationship because it is a renowned place of homosexual relationships among young men, and it gives signs "to her readers that this school was instrumental in creating the homosocial-homoerotic Robert Audley" (Kushnier 2002: 62). In addition, Richard Nemesvari indicates that such elite schools for male students "form the homosocial bonds at the heart of British patriarchal power" (1995: 521) by excluding females. Regarding these earlier implications and background about Robert's sexuality, his close relationship with George Talboy is doubtful and questionable. When George Talboy comes back from Australia and learns that his wife has passed away, he meets his friend Robert Audley from Eton College, and they spend about a year together in Robert's place. During their time of being together, Robert endeavours "to act for another" (44) and makes sure of his companion's comfort, becoming the helper "which [...] guided [George] through the darkest passage of [his] life" (477). Additionally, Robert cannot think of a life without George even after his marriage. He always includes George in his dreams about living in a villa where George "shall lie on the deck and smoke while my pretty one plays her guitar and sings songs to us" (40). Hence, George is always present even when Robert is imagining his future wife is entertaining them.

Robert tells Lady Audley, "I had a friend [...] whom I loved very dearly, and since I have lost him I fear that my feelings towards other people are strangely embittered" (153). Here, he obscurely admits his love of a man, which would not be recognized by the Victorian reader. He has resentful feelings toward other people, and he cannot love another person, especially a woman, because of the power of his affection for George. He later bemoans, "Who would have thought that I could have grown so fond of the fellow [...] or feel so lonely without him? [...] I would freely give up all [...] if [...] George Talboys could stand by my side" (176). The intensity of his emotions could be observed in these words. In the beginning of their friendship, their intimacy and Robert's interest could be related to George's emotional fragility because of his lost wife. Nonetheless, Robert's emotions in this passage imply a stronger bond between the men. When George is lost after his encounter with Lady Audley, Robert is absorbed in thoughts of George and he is "flurried and anxious [...] about his missing friend and [...] walking fast. 'I haven't walked fast since I was at Eton,' he murmured” (90). Robert remembers him in every second after George is lost. Performing a quasi-detective position, he sacrifices his own comfort for the sake of finding his beloved companion. This intimacy between the two men is identical to the strong bond between Marian and Laura in many ways.

Robert's relationship with George's sister Clara also gives the signs of his overwhelming affection for George. Clara's similarity to George prompts Robert to regard her as a companion when they meet because she is "like the friend whom he had loved and lost” (220). It is inevitable to recognize that Robert's emotions for Clara deepen as he observes more of George in her appearance and personality (Kushnier 2002: 68). He 
does not have any sexual or emotional intentions for Clara, which hints his devotion to George and his indifference to Clara.

In addition to his eccentric personality, his hatred for women, similar to Marian's hatred for men, emphasizes the complicated nature of his sexuality. His lack of interest in women is very apparent when he says "I hate women [...] They're bold, brazen, abominable creatures, invented for the annoyance and destruction of their superiors" (227). This is very similar to Marian's discontent with the strength and domination of men. Thus, Robert's remarks about women once again suggest that his relationship to Clara is emptied of sexual and emotional content.

Robert complains about "how these women take life out of our hands. Helen Maldon, Lady Audley, Clara Talboys, and now Miss Tonks--all womankind from beginning to end" (258). This explanation by Robert is again comparable to Marian's thoughts on male dominancy and control over women. This could be seen that weaker men could be disturbed by female malevolence just like the degrading effects of patriarchy on women. Braddon subverts the patriarchal order by presenting a female character challenging this authority who could be a disturbing figure as much as men. Robert also states that women "are the stronger sex, the noisier, the more persevering, the most self-assertive sex" (227). Robert's comment on the strength of women over men is materialized in the novel. Braddon shows Lady Audley as a stronger woman with her wit and cunningness in order to survive in a material and patriarchal society through several plots and intrigues. After disguising herself as a governess which is one of the few jobs for Victorian women, she can wisely display virtuous features as a way of getting married to Sir Michael Audley.

In addition to Robert, Lucy's second husband, "Sir Micheal is femininized to a certain extent" and is not described as a strong and bad-tempered oppressor (Hansson \& Norberg 2013: 445). Sir Michael is entirely reliant upon his younger wife who controls him in all aspects. With his marriage to Lucy, he stops being an independent and powerful aristocrat. In addition, even when Lucy's secrets are revealed, he just leaves home and goes abroad with his daughter. Therefore, both George and Sir Michael seem to be unfortunate victims of female subtlety, while Robert obviously only evades a similar situation as a result of his indifference to women (Klein 2008)

Towards the end of both novels, the subversions of social constructions of gender and sexuality are sustained with unconventional depictions of marriage which include a third person involved. Braddon concludes the novel with George, Robert, and Clara in a "fairy cottage" (478), in spite of no obvious sexual intimacy between the men. Sedgwick explains that these marriages with a third individual use women as conduits to show heterosexual relationships in the eyes of society for the sake of cementing patriarchal order (Sedgwick 1985: 25). Here, the conduit is Clara who unconsciously enables the continuity of Robert and George's relationship. This is very similar to the situation of Walter and Laura and their marriage including Marian as an indispensable part of their 
life, as the sisters promised to each other. In a similar manner to Sedgwick's proposition, Sharon Marcus foregrounds the role of heterosexual marriage in securing the homosocial bonds and friendships between women in the Victorian age (2007: 193). The traditional heterosexual marriage faces a challenge through the ambiguous figures of Marian Halcombe and George Talboys. This shows that homoerotic predilections are still maintained in the house under the disguise of a heterosexual marriage. By presenting these marriages in the two novels, they defy conventional understandings of sexuality and marriage in the Victorian age.

\section{Conclusion}

Wilkie Collins's The Woman in White and Mary Elizabeth Braddon's Lady Audley's Secret overthrow and reinterpret conventional constructions of gender. Unusual characters like Robert Audley and Marian Halcombe do not conform to the traditional stereotypes of masculinity and femininity; however, they are not criticized or portrayed as antipathetic characters, which suggests the intention of the writers to subvert these social and sexual conventions (Klein 2008). Marian is never judged and condemned because of her masculinity; in contrast, she is described like a heroine who resolves a lot of troubles in the story. With his quest for revealing the truth, Robert Audley is also a sympathetic character despite his homoerotic predilections. On the other hand, Lady Audley is justified because of having been left alone by her first husband and having no other choice. Moreover, she transgresses moral and social boundaries by committing crimes and climbing socially through marriage. Her being punished and put in the asylum symbolizes the excessive Victorian morality and intolerance for unconventional women.

As observed, The Woman in White and Lady Audley's Secret are not mere stories of how patriarchy is threatened and overpowered, but they should be recognized as subversions of gender stereotypes. Male characters are depicted as feeble while some women are shown to be strong and they generally control men in addition to merely resisting patriarchy. That is to say, these works complement portrayals of unordinary women with the pictures of peculiar men by defying conventional understandings of femininity and masculinity. Being radical examples of sensation fiction, they make the best of their genre and make a difference in terms of gender and sexuality in a very conventional age. They destabilize sexual and social conventions presenting characters who challenge the perception of what is typical of a certain social class or gender. Consequently, these works transgress gender boundaries and react against mainstream Victorian literary and social traditions by introducing uncommon issues and characters.

\section{References}

Allen, E. 2011. Gender and sensation. In: P.K. Gilbert (ed.), A Companion to Sensation Fiction, 401-413. Oxford: Blackwell Publishing. 
Barry, P. 2002. Beginning Theory: An Introduction to Literary and Cultural Theory. (2nd Edition) Manchester/New York: Manchester University Press.

Bauer, G. 2016. Houses, Secrets, and the Closet: Locating Masculinities from the Gothic Novel to Henry James. Bielefeld: Transcript Verlag.

Braddon, M.E. 2012 [1862]. Lady Audley's Secret. London: Penguin English Library. Collins, W. 1994 [1860]. The Woman in White. London: Penguin Books.

Dever, C. 2005. Everywhere and nowhere: Sexuality in the Victorian fiction, In: F. O'Gorman (ed.), A Concise Companion to the Victorian Novel, 156-179. Oxford: Blackwell Publishing.

Erickson, L. 1999. "In Short, She Is an Angel, and I Am - ": Odd Women and Same-Sex Desire in The Woman in White. In: M. Demarest Button \& T. Reed (eds.), The Foreign Woman in British Literature: Exotics, Aliens, and Outsiders. Westport, CT: Greenwood Press.

Forman, R.G. 2011. Queer sensation. In: P.K. Gilbert (ed.), A Companion to Sensation Fiction, 414-429. Oxford: Blackwell Publishing.

Hammond, P. 1996. Love between Men in English Literature. New York: St. Martin's Press.

Hansson, H. \& Norberg, C. 2013. Lady Audley's secret, gender and the representation of emotions. Women's Writing 20:4: 441-457.

Klein, H.G. 2008. Strong women and feeble men: upsetting gender stereotypes in Mary Elizabeth Braddon's Lady Audley's Secret. Atenea 28:1: 161-174.

Kushnier, J.S. 2002. Educating boys to be queer: Braddon's Lady Audley's Secret. Victorian Literature and Culture 30:1: 61-75.

Marcus, S. 2007. Between Women: Friendship, Desire, and Marriage in Victorian England. Princeton/Oxford: Princeton University Press.

Miller, D. A. 1986. Cage Aux Folles: Sensation and gender in Wilkie Collins's The Woman in White. Representations 14 (Spring): 107-136.

Nemesvari, R. 1995. Robert Audley's secret: Male homosocial desire in Lady Audley's Secret. Studies in the Novel 27:4 (Winter): 515-28.

Pykett, L. 2005. Wilkie Collins. Oxford: Oxford University Press.

Schroeder, N. 1988. Feminine sensationalism, eroticism and self-assertion. Tulsa Studies in Women's Literature 7:1 (Spring): 87-103.

Sedgwick Kosofsky, E. 1985. Between Men: English Literature and Male Homosocial Desire. New York: Colombia University Press.

$* * *$

Sercan Öztekin is a Lecturer of English at Kocaeli University, Turkey. He received his Bachelor's Degree from Dumlupinar University, Turkey, the Department of English Language and Literature, and Master's Degree from Granada University, Spain. He obtained his Ph.D. degree in Istanbul Aydin University in 2019. His Ph.D. study is on 
Victorian social constructions of crime, criminality, and the legal system with their representations in the novels of Wilkie Collins, Charles Dickens, and Charles Reade in the 1850s. His research includes Victorian literature and culture, crime fiction, and the history of crime and the police. 